УДК 633.31:631.674.6

DOI https://doi.org/10.32848/agrar.innov.2021.5.24

\title{
ВРОЖАЙНІСТЬ ТА ПОСІВНІ ЯКОСТІ НАСІННЯ СОРТІВ ЛЮЦЕРНИ В УМОВАХ ЗРОШЕННЯ ЗАЛЕЖНО ВІД ЗАСТОСУВАННЯ БАКТЕРІАЛЬНИХ ПРЕПАРАТІВ
}

\author{
ТИщЕНКО А.В. - кандидат сільськогосподарських наук \\ https://orcid.org/0000-0003-1918-6223 \\ Інститут зрошуваного землеробства Національної академії аграрних наук України \\ ТИЩЕНкО О.Д. - кандидат сільськогосподарських наук, \\ старший науковий співробітник \\ https://orcid.org/0000-0002-8095-9195 \\ Інститут зрошуваного землеробства Національної академії аграрних наук України \\ ДимОВ О.М. - кандидат сільськогосподарських наук, старший науковий співробітник \\ https://orcid.org/0000-0002-7839-0956 \\ Інститут зрошуваного землеробства Національної академії аграрних наук України \\ ПІляРСькА О.О. - кандидат сільськогосподарських наук \\ https://orcid.org/0000-0001-8649-0618 \\ Інститут зрошуваного землеробства Національної академії аграрних наук України \\ ГАЛЬЧЕНКО Н.М. - кандидат сільськогосподарських наук \\ https://orcid.org/0000-0002-1717-5101 \\ Асканійська державна сільськогосподарська дослідна станція \\ Інституту зрошуваного землеробства Національної академії аграрних наук України
}

Постановка проблеми. Люцерна (Medicago sativa L.) - найважливіша багаторічна кормова рослина сімейства бобових [1-5]. Вона зростає в ареалі від розпечених пустель, низькогір'я до високогірних масивів (2 500-3 000 м над рівнем моря) і широт із холодним континентальним кліматом та добре адаптується до умов довкілля, даючи високі врожаї і добру якість кормів $[6 ; 7 ; 8 ; 9]$.

Як і інші сільськогосподарські культури, вона розмножується насінням, а воно є носієм біологічних і господарсько-цінних властивостей рослин, тому повинне мати високі посівні якості, що впливають на подальшу врожайність [10; 11]. Цінність насіннєвого матеріалу залежить від комплексу фракторів. Якість його визначається природою генотипу сорту та умовами навколишнього середовища в період їх формування, розвитку та зберігання. До основних факторів, що впливають на якість насіння, належать погодні умови під час формування насіння (екологічні умови) і прийоми агротехніки [12].

Аналіз останніх досліджень і публікацій. Під час використання методів селекції створено низку сортів, які характеризуються високою продуктивністю та підвищеною якістю кормів, підвищеним рівнем азотфіксуючої здатності та потужною кореневою системою $[1 ; 4$; 13-16]. Проте розширення площ під цією цінною культурою лімітується ії̈ низькою насіннєвою продуктивністю, тому збільшення виробництва та покращення посівних якостей насіння люцерни можливе за рахунок поліпшення методів вирощування. За даними Bolanos-Aguilar et al. [17], дослідження в галузі генетики та селекції показали, що прогрес у досягненні більш високого врожаю насіння люцерни обмежений. 3 іншого боку, оптимальне використання мінерального живлення [18-21], застосування поліфункціональних багатокомпонентних бактеріальних препаратів [22-30], регуляторів росту [31], запилювачів [32; 33], відстань між рядами, кількість насіння, що використовується для сівби, і площа жив- лення рослин [34] мають значний вплив на формування компонентів продуктивності та формування врожаю, здається, що це найкращий шлях для досягнення більш високої і стабільної насіннєвої продуктивності [35; 36].

Підвищення насіннєвої продуктивності люцерни $€$ надзвичайно важливим і складним питанням, яке можливо вирішити шляхом розроблення більш досконалої технології вирощування. Сутність ії̈ зводиться до доповнення звичайної агротехніки комплексом спеціальних прийомів, які прямо чи побічно поліпшують процеси росту і розвитку, утворення генеративних органів та підвищують врожайність насіння люцерни. Утворення та розвиток насіння на рослині люцерни відбуваються неодночасно, що зумовлює різну забезпеченість їх поживними речовинами. Чималу роль у формуванні повноцінного насіння відіграють умови живлення рослин, оскільки поживні елементи беруть участь у багатьох реакціях синтезу та обміну речовин, входячи до складу білків, нуклеїнових кислот та інших сполук. Насіння буде володіти високими якостями, якщо співвідношення елементів живлення буде оптимальним [4; 37; 38].

Для формування високої насіннєвої продуктивності та покращення посівних якостей насіння люцерни необхідне підвищення агрофрону за рахунок вжиття комплексу агротехнічних та організаційних заходів, освоєння науково обґрунтованої зональної системи землеробства. При цьому важливим є використання нових біологічних засобів, які підвищують біологічну активність ґрунту, покращують азотфіксацію, сприяють перетворенню фосфорних та калійних сполук на доступні для рослин форми та покращують їх засвоєння, захищають рослини від хвороб і шкідників, підвищують імунітет та стійкість до стресів, стимулюють ріст рослин [39-41].

Нині увага до біологічних методів обумовлена перш за все тим, що це єдиний екологічно чистий шлях 
забезпечення рослин елементами живлення, за якого принципово неможливо забруднення природного середовища [42]. В умовах ринкових відносин за високої вартості мінеральних добрив це $є$ найбільш доступним засобом отримання якісного насіння сільськогосподарських культур, оскільки симбіотична фріксація азоту здійснюється за рахунок природних ресурсів, що дає змогу знизити енерговитрати в землеробстві [43].

Унікальні функції мікроорганізмів із фіксації атмосферного азоту набувають особливого значення у зв'язку 3 посиленням антропогенного впливу на агроекосистеми і можливістю використання біологічних механізмів живлення рослин. Це дає змогу в майбутньому перейти від сучасного «хімічного» землеробства до конструювання агробіоценозів на біологічній основі [44].

Раніше проводилися дослідження з вивчення впливу мікробіологічних добрив і біопрепаратів на різних польових культурах [45; 46]. Було відзначено ефективність застосування різних мікробіологічних препаратів та їх позитивний вплив, що проявляється у збільшенні кількості бобів і насіння з рослини, маси 1000 насінин та, відповідно, підвищенні врожайності і якості насіння сільськогосподарських культур [47].

Виходячи з аналізу вітчизняного і зарубіжного наукового матеріалу, в дослідження ми включили ризобофріт, комплекс біопрепаратів (КБП), ціанорізобіальний консорціум (ЦБК) і ціанорізобіальний препарат (ЦБП), щоб виділити нові форми ефективних бактеріальних препаратів для включення кращих у технологію вирощування люцерни.

Мета статті полягає у визначенні впливу бактеріальних препаратів на насіннєву продуктивність люцерни другого року життя, енергію проростання та лабораторну схожість насіння.

Матеріали та методика досліджень. Завданнями дослідження $€$ розроблення та наукове обґрунтування агротехнічних прийомів підвищення насіннєвої продуктивності і посівних якостей насіння люцерни.

Дослідження проводили протягом 2016-2018 рр. на дослідному полі Інституту зрошуваного землеробства НААН. У ґрунтово-кліматичному аспекті воно розташоване в степовій зоні, на Інгулецькому зрошуваному масиві.

Метод закладки польового досліду - розщеплені ділянки. Головні ділянки (фактор А) - сорти люцерни (Унітро і Зоряна); субділянки (фактор В) - обробка насіння бактеріальними препаратами з розрахунку $1 \%$ від маси насіння без розведення водою в день посіву: 1 - контроль (без обробки); 2 - Ризобофріт (на специфрічному високоефективному штамі бульбочкових бактерій 404б); 3 - Комплекс біопрепаратів (КБП), що включає симбіотичні азотфіксуючі, фосфратмобілізуючі і біопротекторні мікроорганізми з функціональними властивостями біопрепаратів, а саме Ризобофріту, Фосфоентеріну і Біополіциду (1:1:1), які характеризуються комплексним впливом на бобові культури; 4 - Ціанобактеріальний консорціум (ЦБК) - гомогенат на основі рістстимулюючих ціанобактерій штаму 144 і бульбочкових бактерій штаму $404^{\sigma} 3$ первинними і вторинними метаболітами; 5 - Ціанобактеріальний препарат (ЦБП) на основі рістстимулюючих ціанобактерій штаму 144 і бульбочкових бактерій штаму 404б з первинними метаболітами. Строк сівби ранньовесняний. Посів широкорядковий $з$ міжряддям $70 \mathrm{~cm}$. Площа посівної ділянки становить $60 \mathrm{~m}^{2}$, облікової - 40 м², повторність триразова.

Статистичну обробку експериментальних даних проводили з використанням програм AgroSTAT, XLSTAT, Statistica (v. 13)

Результати досліджень. Отримані експериментальні дані свідчать про різну реакцію сортів люцерни на бактеріальні препарати. Насіннєва продуктивність під час інокуляції бульбочковими бактеріями (Ризобофіт) була вищою на 16,0-20,0\% порівняно 3 контролем і склала 271,8 кг/га у сорту Зоряна та 361,9 кг/га сорту Унітро. Проте ефективність монокультури (Ризобофріт) щодо врожайності насіння була нижчою від полікомпонентних препаратів (КБП) на основі Ризобофріту, Фосфоентеріну й Біополіциду з урожайністю насіння 303,6 кг/га (сорт Зоряна) та 398,8 кг/га (сорт Унітро). Слід зазначити, що у асоціацій з ціанобактеріями ЦБК і ЦБП зазначалася сильно виражена стимулююча дія. Високу ефективність показав ціанорізобіальний консорціум (ЦБК) (337,3; 424,6 кг/га), але найбільшу насіннєву продуктивність отримали на варіанті із застосуванням ЦБП, а саме 361,1 та 456,4 кг/га у сортів Зоряна і Унітро відповідно (табл. 1).

В результаті досліджень установлено, що істотне підвищення показників посівних якостей насіння люцерни відзначено за інокуляції препаратами Ризобофіт, КБП, ЦПК, ЦПП. Інокуляція насіння сприяла збільшенню маси 1000 насінин порівняно з аналогічними показниками в контрольних варіантах: у сорту Унітро до 2,02-2,05 г, у сорту Зоряна до 2,03-2,06 г, або на 0,03-0,06 г.

Вирощене насіння характеризувалося високими посівними якостями. Енергія проростання (EGS) через 3 місяці на контролі склала $76 \%$ у сорту Унітро і $73 \%$ у сорту Зоряна, а лабораторна схожість (LGS) - 85\% і 83\% відповідно. Інокуляція бактеріальними препаратами сприяла підвищенню показника EGS у сорту Унітро до 79-83\%, сорту Зоряна - до 78-84\%, а лабораторної схожості - до 87-92\% і 86-93\% відповідно.

У результаті досліджень установлено, що енергія проростання насіння люцерни після 6 місяців зберігання склала в середньому у сорту Унітро 83-90\%, у сорту Зоряна - 78-87\%, а лабораторна схожість - 92-97\% і 85-94\% відповідно. В ході досліджень установлено, що енергія проростання насіння, що зберігалося 1 рік, вища на $8-10 \%$ у сорту Унітро і на 12-15\% у сорту Зоряна, а лабораторна схожість - на $1-4 \%$ і 8-10\% відповідно, ніж у насіння, що зберігалося 6 місяців.

Дані деяких авторів вказують на стимуляцію росту і розвитку рослин під впливом штучних консорціумів ціанобактерій і різних видів Rhizobium, що сприяє підвищенню їх врожайності [48; 49; 50].

Аналіз отриманих результатів показує, що застосування ціаноризобіальних консорціумів сприяє різкому підвищенню насіннєвої продуктивності порівняно як із контролем, так і моноінокуляцією. 
Таблиця 1 - Урожайність та посівні якості насіння сортів люцерни залежно від застосування бактеріальних препаратів (середнє за 2016-2018рр.)

\begin{tabular}{|c|c|c|c|c|c|c|c|c|c|}
\hline \multirow{3}{*}{$\begin{array}{l}\overline{8} \\
\frac{0}{0} \\
\frac{5}{0} \\
\frac{0}{0} \\
\frac{8}{0} \\
\frac{5}{0} \\
0\end{array}$} & \multirow[b]{3}{*}{$\begin{array}{c}\text { Застосування бактеріальних } \\
\text { препаратів (фактор В) }\end{array}$} & \multirow{3}{*}{ 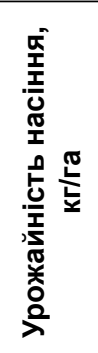 } & \multirow{3}{*}{ 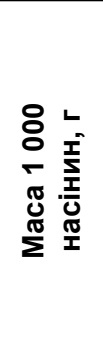 } & \multicolumn{6}{|c|}{ Показники якості насіння, \% } \\
\hline & & & & \multicolumn{2}{|c|}{3 місяці } & \multicolumn{2}{|c|}{6 місяців } & \multicolumn{2}{|c|}{1 рік } \\
\hline & & & & 岛 & త્ય & 岛 & S્] & 心 & త্] \\
\hline \multirow{6}{*}{$\frac{\stackrel{ }{2}}{\frac{1}{x}}$} & Контроль 1 (без обробок) & 307,5 & 1,99 & 76 & 85 & 83 & 92 & 91 & 93 \\
\hline & Ризобофріт & 369,1 & 2,02 & 79 & 87 & 86 & 93 & 95 & 96 \\
\hline & КБП (комплекс біопрепаратів) & 398,8 & 2,03 & 81 & 87 & 87 & 94 & 96 & 97 \\
\hline & ЦБК (ціанобактеріальний консорціум) & 424,6 & 2,04 & 82 & 90 & 88 & 95 & 97 & 99 \\
\hline & ЦБП (ціанобактеріальний препарат) & 456,4 & 2,05 & 83 & 92 & 90 & 97 & 98 & 99 \\
\hline & Середнє & 391,3 & 2,02 & 80 & 88 & 87 & 94 & 95 & 97 \\
\hline \multirow{6}{*}{ 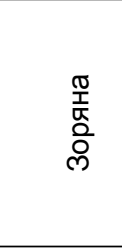 } & Контроль 1 (без обробок) & 234,1 & 2,00 & 73 & 83 & 78 & 85 & 90 & 94 \\
\hline & Ризобофіт & 271,8 & 2,03 & 78 & 86 & 80 & 87 & 92 & 96 \\
\hline & КБП (комплекс біопрепаратів) & 303,6 & 2,04 & 79 & 88 & 81 & 88 & 93 & 97 \\
\hline & ЦБК (ціанобактеріальний консорціум) & 337,3 & 2,05 & 82 & 90 & 84 & 91 & 97 & 99 \\
\hline & ЦБП (ціанобактеріальний препарат) & 361,1 & 2,06 & 84 & 93 & 87 & 94 & 98 & 99 \\
\hline & Середнє & 301,6 & 2,03 & 79 & 88 & 82 & 89 & 94 & 97 \\
\hline \multicolumn{10}{|c|}{ Оцінка істотності часткових відмінностей } \\
\hline $\mathrm{HIP}_{05}$ & A & 23,76 & 0,085 & 2,8 & 3,7 & 2,2 & 2,7 & 1,0 & 1,3 \\
\hline $\mathrm{HIP}_{05}$ & B & 18,61 & 0,013 & 1,4 & 1,9 & 1,2 & 1,6 & 0,6 & 1,0 \\
\hline \multicolumn{10}{|c|}{ Оцінка істотності головних ефектів } \\
\hline $\mathrm{HIP}_{05}$ & A & 10,63 & 0,038 & 1,6 & 1,7 & 1,3 & 1,5 & 0,7 & 1,1 \\
\hline $\mathrm{HIP}_{05}$ & B & 13,16 & 0,009 & 1,0 & 1,4 & 0,8 & 1,2 & 0,4 & 0,8 \\
\hline
\end{tabular}

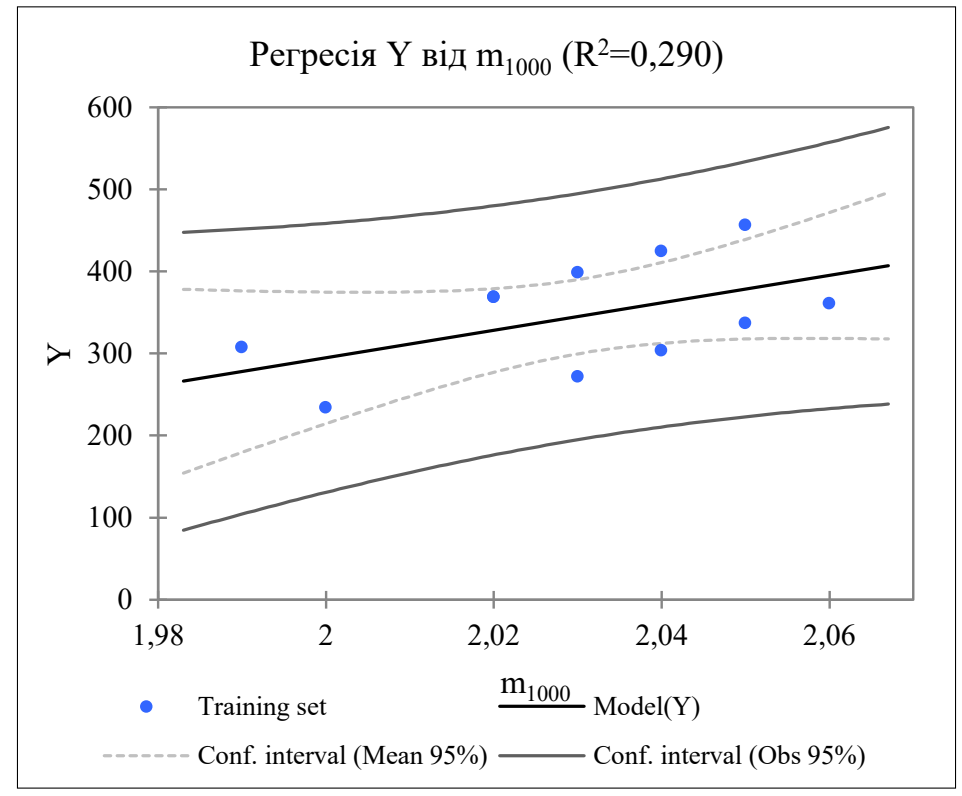

Рис. 1. Діаграма регресії врожайності насіння (Y) від маси 1000 насінин (m1000)

Діаграма дає нам змогу візуалізувати дані, лінію регресії (встановлена модель Model (Y)) та два довірчі інтервали, такі як довірчий інтервал середнього зна- чення прогнозу (Conf. interval (Mean 95\%)) для цього значення $\mathrm{m}_{1000}$ та довірчий інтервал для одного прогнозу для цього значення $\mathrm{m}_{1000 .}$ 


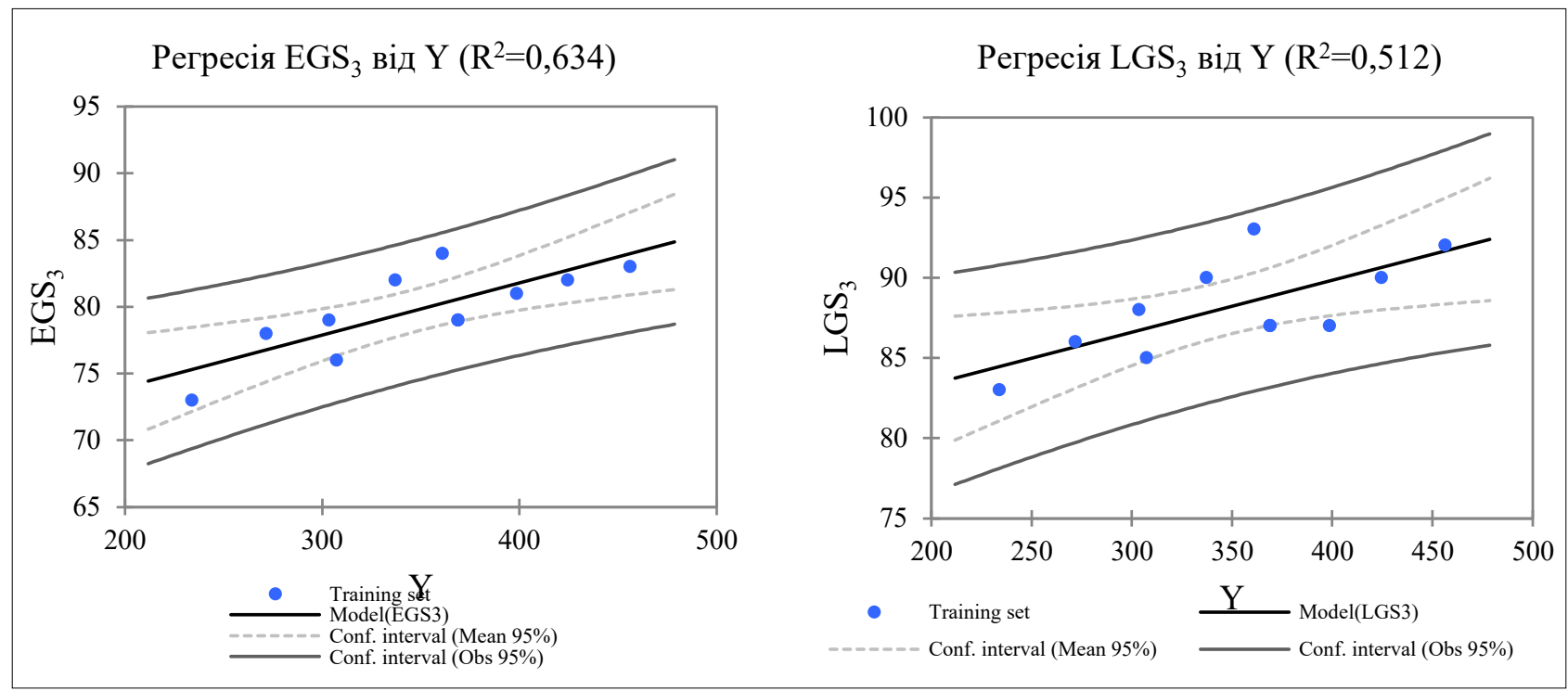

Рис. 2. Діаграма регресії енергії проростання насіння через 3 місяці (EGS $)$ (зверху) і лабораторної схожості насіння через 3 місяці (LGS $)_{3}$ (знизу) від врожайності насіння (Y)

Діаграма дає нам змогу візуалізувати дані, лінію регресії (встановлена модель Model $\left(E S_{3}\right)$ i Model $\left.\left(\mathrm{LGS}_{3}\right)\right)$ та два довірчі інтервали, такі як довірчий інтер- вал середнього значення прогнозу (Conf. interval (Mean 95\%)) для цих значень $\mathrm{EGS}_{3}$ i LGS 3 та довірчий інтервал для одного прогнозу для цього значення $\mathrm{EGS}_{3}$ i LGS 3 .
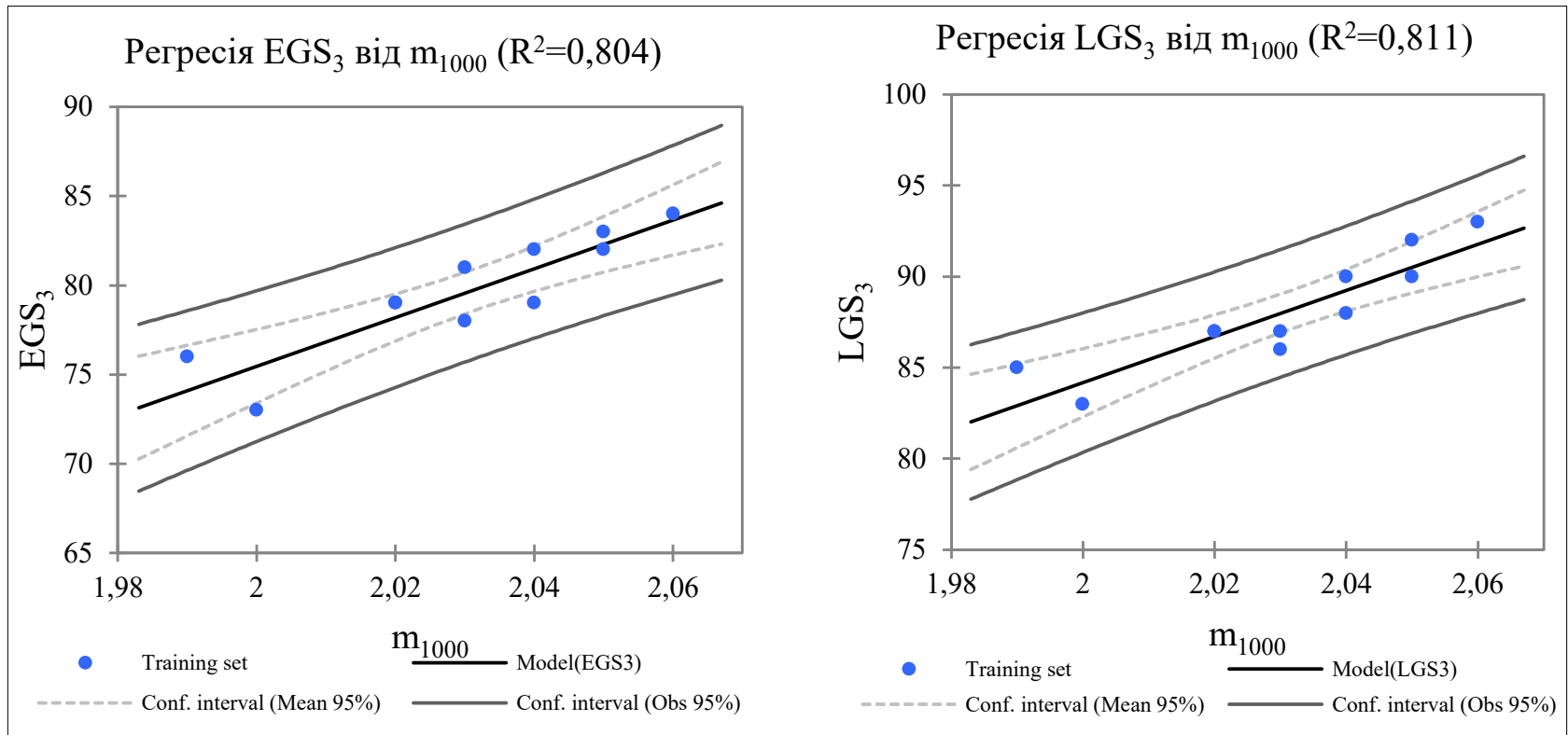

PUс. 3. Діаграма регресії енергії проростання насіння через 3 місяці (EGS3) (зверху) і лабораторної схожості насіння через 3 місяці (LGS3) (знизу) від маси 1000 насінин (m1000)

Діаграма дає нам змогу візуалізувати дані, лінію регреciї (встановлена модель Model $\left(\mathrm{EGS}_{3}\right)$ і Model $\left(\mathrm{LGS}_{3}\right)$ ) та два довірчі інтервали, такі як довірчий інтервал серед- нього значення прогнозу (Conf. interval (Mean 95\%)) для цих значень $\mathrm{EGS}_{3}$ і LGS 3 та довірчий інтервал для одного прогнозу для цього значення $\mathrm{EGS}_{3}$ i LGS $_{3}$. 


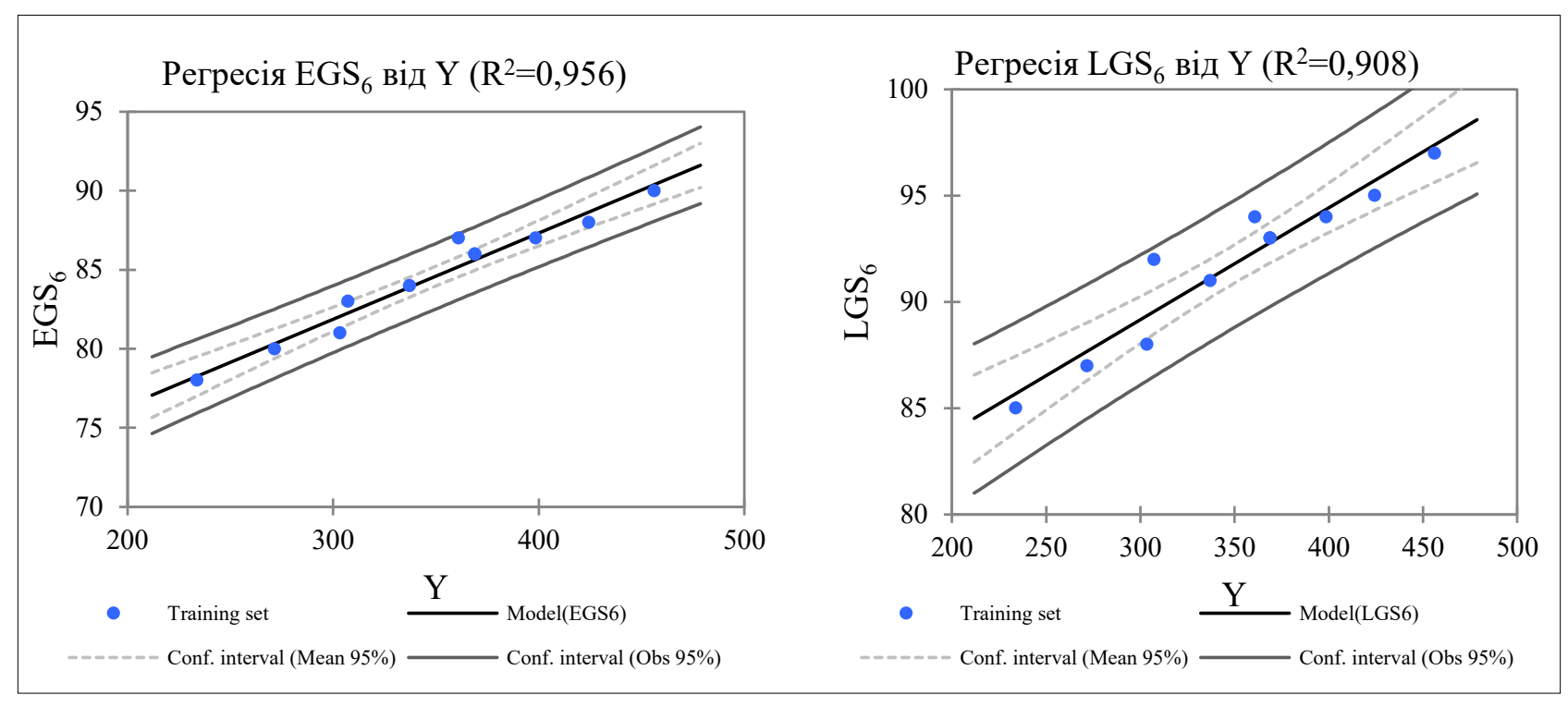

Рuc. 4. Діаграма регресії енергії проростання насіння через 6 місяців (EGS6) (зверху) і лабораторної схожості насіння через 6 місяців (LGS6) (знизу) від врожайності насіння (Y)

Діаграма дає нам змогу візуалізувати дані, лінію регреciï (встановлена модель Model (EGS6) і Model (LGS $)$ ) та два довірчі інтервали, такі як довірчий інтервал серед- нього значення прогнозу (Conf. interval (Mean 95\%)) для цих значень $\mathrm{EGS}_{6}$ i LGS 6 та довірчий інтервал для одного прогнозу для цього значення $\mathrm{EGS}_{6}$ i LGS 6 .
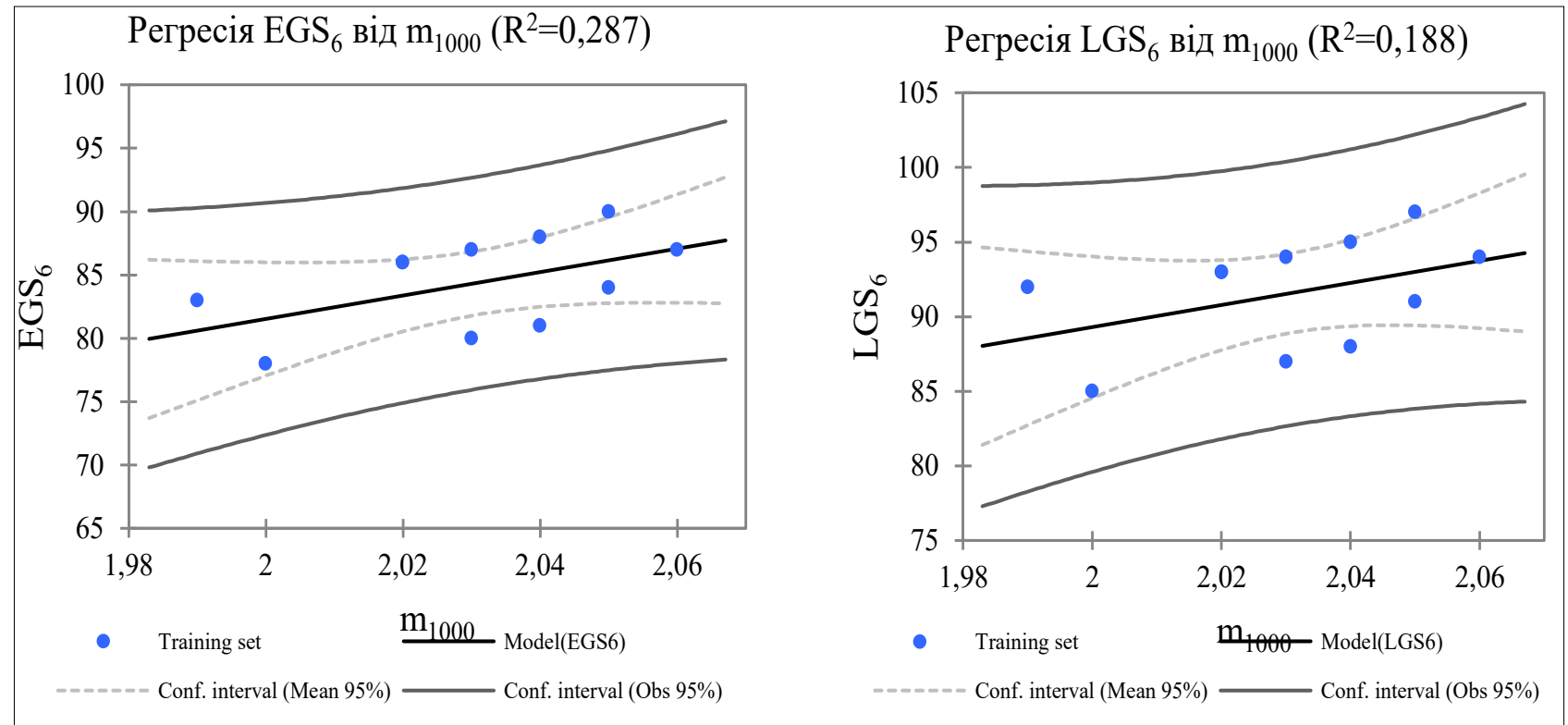

Puc. 5. Діаграма регресії енергії проростання насіння через 6 місяців (EGS6) (зверху) й лабораторної схожості насіння через 6 місяців (LGS6) (знизу) від маси 1000 насінин (m1000)

Діаграма дає нам змогу візуалізувати дані, лінію регреciï (встановлена модель Model (EGS 6 ) і Model (LGS6)) та два довірчі інтервали, такі як довірчий інтервал серед- нього значення прогнозу (Conf. interval (Mean 95\%)) для цих значень EGS 6 i LGS 6 та довірчий інтервал для одного прогнозу для цього значення EGS 6 i LGS 6 . 


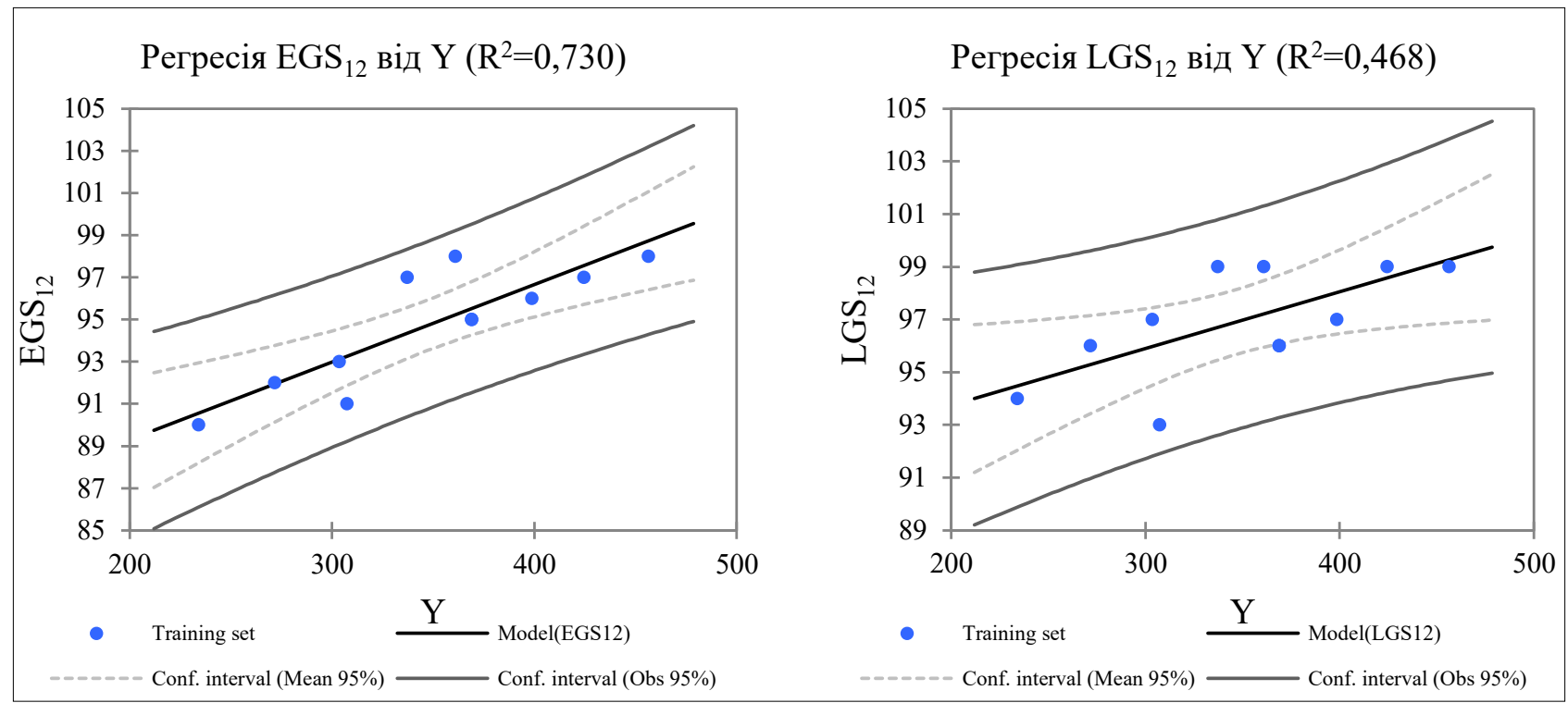

Рис. 6. Діаграма регресії енергії проростання насіння через 12 місяців (EGS12) (зверху) й лабораторної схожості насіння через 12 місяців (LGS12) (знизу) від врожайності насіння (Y)

Діаграма дає нам змогу візуалізувати дані, лінію регресії (встановлена модель Model $\left(E_{G S}\right)$ і Mode $\left(\right.$ LGS $\left.\left._{12}\right)\right)$ та два довірчі інтервали, такі як довірчий інтер- вал середнього значення прогнозу (Conf. interval (Mean $95 \%)$ для цих значень $\mathrm{EGS}_{12}$ i LGS $_{12}$ та довірчий інтервал для одного прогнозу для цього значення $\mathrm{EGS}_{12}$ i LGS $_{12}$.
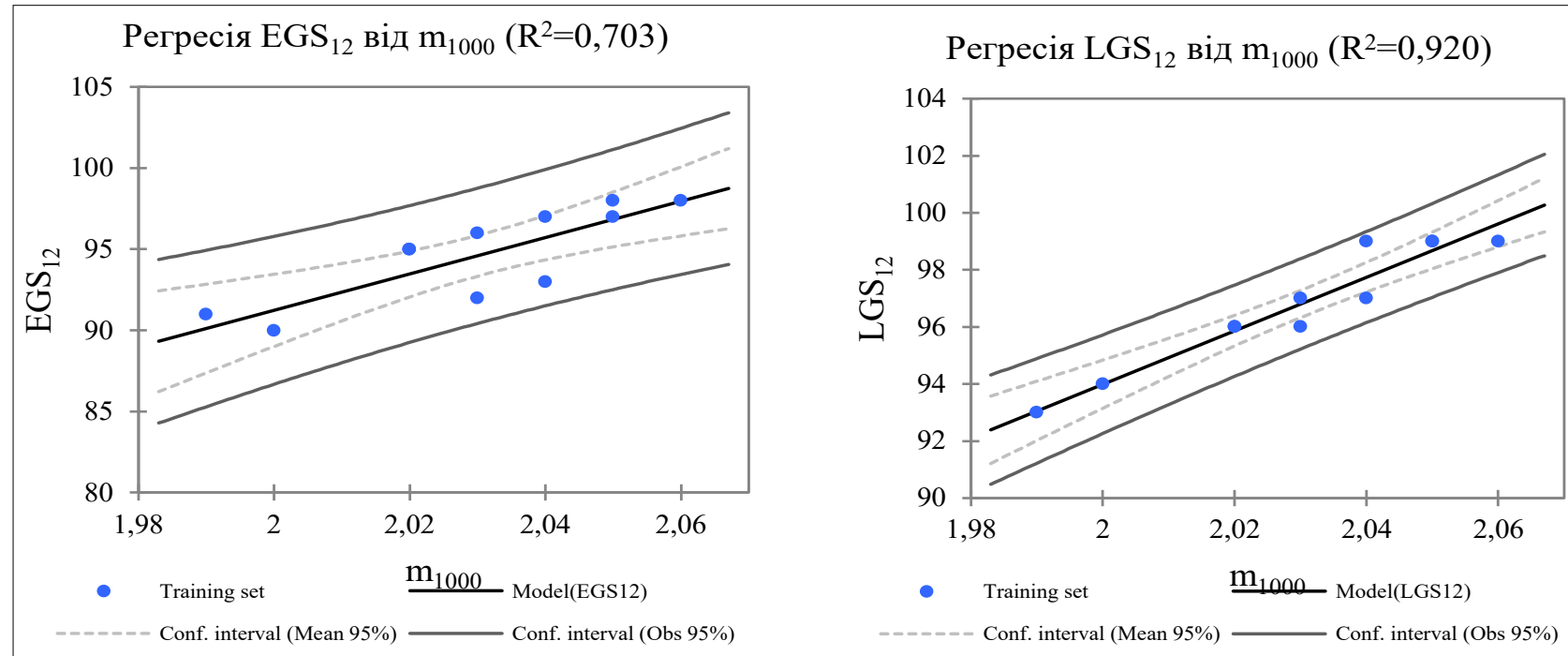

Puc. 7. Діаграма регресії енергії проростання насіння через 12 місяців (EGS12) (зверху) й лабораторної схожості насіння через 12 місяців (LGS12) (знизу) від маси 1000 насінин (m1000)

Діаграма дає нам змогу візуалізувати дані, лінію регресії (встановлена модель Model $\left(E_{G S}\right)$ і Model $\left.\left(\mathrm{LGS}_{12}\right)\right)$ та два довірчі інтервали, такі як довірчий інтервал середнього значення прогнозу (Conf. interval (Mean 95\%)) для цих значень $\mathrm{EGS}_{12}$ і $\mathrm{LGS}_{12}$ та довірчий інтервал для одного прогнозу для цього значення $\mathrm{EGS}_{12}$ i LGS ${ }_{12}$.

Висновки. Дослідженнями встановлено, що застосування бактеріальних препаратів істотно збільшувало насіннєву продуктивність, масу 1000 насінин та покращувало їх посівні якості. Найбільший врожай насіння було отримано у сорту Унітро за оброблення насіння ціанобактеріальним препаратом (ЦБП), а саме 456,4 кг/га. Найбільшу масу 1000 насінин отримали у сорту Зоряна за оброблення насіння ціанобактеріальним препаратом, що становила 2,06 г. Коефріцієнт детермінації між врожайністю насіння та масою 1000 насінин був таким: $\mathrm{R}^{2}=0,290$. 
Список використаної літератури:

1. Radović J., Sokolović D., Marković J. Alfalf-most important perennial forage legume in animal husbandry. Biotechnology in Animal Husbandry. 2009. Vol. 25. Issue 5-6. P. 465-475, ISSN 1450-9156. DOI: https://doi.org/10.2298/BAH0906465R.

2. Sokolović D. et al. Genetic resources of perennial forage grasses in Serbiaa: Current State, Broadening and Evaluation. Selekcija i semenarstvo. 2017. Vol. XXIII. Broj. 1. P. 69-82. DOI: 10.5937/SelSem1701069S

3. Moga I., Schitea M. Tehnologii moderne de producere a seminţelor la plantele furajere. Ed. Ceres, Bucuresti. 2005. № 288. P. 23-54. ISBN 9734007300.

4. Stanisavljević R. Influence of plant density on yield components, yield and quality of seed and forage yields of alfalfa varieties. Romanian Agricultural Research. 2012. Vol. 29. P. 245-254.

5. Knezevic J. Application of corn meal at ensiling of alfalfa cocksfoot and their mixture. Acta agriculturae Serbica. 2014. Vol. 19. P. 143-150. DOI: 10.5937/ AASer1438143K

6. Iannucci A., Di Fonzo N., Martiniello P. Alfalfa (Medicago sativa L.) seed yield and quality under different forage management systems and irrigation treatments in a Mediterranean environment. Field Crops Res. 2002. Vol. 78. Issue 1. P. 65-74. DOI: https://doi.org/10.1016/S0378-4290(02)00094-1.

7. Karamanos A., Papastylianou P., Stavrou J. \& Avgoulas C. Effects of Water Shortage and Air Temperature on Seed Yield and Seed Performance of Lucerne (Medicago sativa L.) in a Mediterranean Environment. J. Agron. \& Crop Sci. 2009. Vol. 195. Num. 6. P. 408-419. ISSN 0931-2250. URL: http://pascal-francis.inist.fr/vibad/ index.php?action=getRecordDetail\&idt=22115435.

8. Putnam D., Russelle M. Alfalfa, wildlife and the environment. The importance and benefits of alfalfa in the 21st century. California : Alfalfa and Forage Association, 2001. 24 p.

9. Muthukumar Bagavathiannan, Rene C Van Acker. The Biology and Ecology of Feral Alfalfa (Medicago sativa L.) and Its Implications for Novel Trait Confinement in North America. Critical Reviews in Plant Sciences. 2009. Vol. 28. Issue 1-2. P. 69-87. DOI: 10.1080/07352680902753613.

10. Гафаров Ф.С. Совершенствование приемов возделывания люцерны на семена в условиях Южной Лесостепи Республики Башкортостан : автореф. дисс. ... канд. с.-х. наук : спец. 06.01.01. Уфра, 2012. 19 с.

11. Денисов Е.А. Совершенствование технологических приемов возделывания люцерны на зеленую массу и семена в Степной зоне Кузнецкой котловины : автореф. дисс. ... канд. с.-х. наук : спец. 06.01.01. Барнаул, 2010. 21 с.

12. Орлюк А.П., Гончарова К.В. Адаптивний і продуктивний потенціал пшениці. Херсон, 2002. С. 239-242.

13. Schitea M. et al. New Romanian cultivars of alfalfa developed at NARDI Fundulea. Romanian Agric. Res. 2007. No. 24. P. 47-50.

14. Petolescu C. et al. Intra-Population Genetic Diversity in Romanian Alfalfa Cultivars as Revealed by SSR Markers. Roman. Biotechnolog. Lett. 2010. Vol. 15. No. 2. P. 107-112.

15. Тищенко О.Д., Тищенко А.В. Напрями селекції люцерни для умов зрошення. Зрошуване землеробcmвo. 2014. № 62. С. 93-95.
16. Тищенко О.Д., Тищенко А.В. Сорти селекції Інституту зрошуваного землеробства. Насінництво. 2014. № 3. C. 10-11.

17. Bolanos-Aguilar E. D. et al. Genetic control of alfalfa seed yield and its components. Plant Breed. 2000. Vol. 120. Issue 1. P. 67-72. DOI: https://doi.org/ 10.1046/j.14390523.2001.00554.x.

18. Kabir et al. Effect of sowing time and cultivars on the growth and yield of chickpea under rainfed condition. Bangladesh J. Agric. Res. 2009. Vol. 34. Issue 2. P. 335-342. ISSN 0258-7122.

19. Tiwari D. et al. Effect of Sowing Dates and Weed Management on Growth and Yield of Chickpea in IndoGangetic Plains. Proc. Natl. Acad. Sci., India, Sect. B Biol. Sci. 2016. Vol. 86. P. 33-38. DOI: https://doi.org/ 10.1007/s40011-014-0396-6.

20. Gossen B.D., Ukrainetz H., Soroka, J.J. Effect of fertilizer on seed yield of alfalfa under irrigation in Saskatchewan. Can. J. Plant Sci. 2004. Vol. 84. No. 4. P. 1105-1108. DOI: https://doi.org/10.4141/P03-136.

21. Terzić D. The effect of cutting schedule, fertilization with micronutrients and plant growth regulation on yield and quality of alfalfa seed (Medicago sativa L.). Ph.D. Thesis. University of Belgrade, Faculty of Agriculture Belgrade, 2011.

22. Калинин А.А., Ковина А.Л., Трефрилова Л.В. Опыт применения препаратов клубеньковых бактерий для повышения продуктивности бобовых культур. Экология родного края: проблемы и пути их решения : сборник материалов XII Всероссийской научно-практической конференции с международным участием. 2017. С. 293-298.

23. Пташец О.В. Способы регулирования ростовых процессов люцерны посевной. Мелиорация. 2013. № 1. С. $162-170$.

24. Панкратова Е.М. и др. Конструирование микробных культур на основе сине-зеленой водоросли Nostoc paludosum Kütz. Альгология. 2004. T. 14. № 4. C. 445-458.

25. Pankratova Je.M. et al. Designing of microbial binary cultures based on blue-green algae (Cyanobacteria) Nostoc paludosum Kütz. International Journal on Algae. 2004. Vol. 6. No. 3. P. 290-304.

26. Трефилова Л.В., Зяблых Р.Ю., Ковина А.Л., Калинин А.А. Эфрфективность цианобактериальных консорциумов при выгонке рассады капусты в защищенном грунте. 80 лет сельскохозяйственному образованию и науки на Урале: Итоги и перспективы : материалы Всероссийской научно-практической конференции ученых и специальностей АПК. 1998. Вып. 11. С. 116-117.

27. Наумкина Т.С. и др. Повышение эффрективности биологической азотфиксации зернобобовых культур. Земледелие. 2012. № 5. С. 21-23.

28. Park J., Bolan N., Mallavarapu M., Naidu R. Enhancing the solubility of insoluble phosphorus compounds by phosphate solubilizing bacteria. 19-th World Congres of Soil Science. Brisbane, Australia. 2010. P. 65-68.

29. Yasmin H., Bano A. Isolation and characterization of phosphate solubilizing bacteria from rhizosphere soil of weeds of khewra salt range and attock. Pakistan Journal of Botany. 2011. № 3. P. 1663-1668.

30. Rodriguez H., Fraga R., Gonzalez T., Bashan Y. Genetics of phosphate solubilization and its potential applications for improving plant growth promoting 
bacteria. Plant and Soil. 2006. 287. P. 15-21. DOI: 10.1007/s11104-006-9056-9.

31. Zhang T. at all. Plant growth regulator effects on balancing vegetative and reproductive phases in alfalfa seed yield. Agron. J. 2009. Vol. 101. Issue 5. P. 1139-1145. DOI: https://doi.org/10.2134/agronj2009.0017.

32. Jevtić G., Radović J., Lugić $Z$. The effect of melliferous bee (Apis mellifera carnica Poll.) and mechanical means on seed yield, yield components and quality of alfalfa seed (Medicago sativa L.). Plant Breeding and Seed Produc. 2005. Vol. XI. No. 1-4. P. 63-68.

33. Andjelković B. et al. The influence of alfalfa flower coloration and the period of the day on the pollinator visits. Biotechnol. in Anim. Husban. 2010. Vol. 26. P. 173-180.

34. Zhang T. et al. Effects of between-row and within-row spacing on alfalfa seed yields. Crop Sci. 2008. Vol. 48. Issue 2. P. 794-803. DOI: 10.2135/cropsci2007.06.0340.

35. Arvind Kumar P.R., Channakeshava B.C. and Siddaraju R. Effect dates of sowing and cutting time on seed yield and quality of alfalfa (Medicago sativa L.) CV. RL-88. Indian Journal of Agricultural Research. 2017. Vol. 51. P. 493-497. DOI: 10.18805/ IJARe.A-4804.

36. Gawariya S.C., Chopra N.K., Chopra N., Harika A.S. Effect of date of sowing and crop geometry on growth and yield parameters of forage mustard (Var. Chinese cabbage). African J. Agric. Res. 2015. Vol. 10 (33). P. 3292-3295. DOI: https://doi.org/ 10.5897/AJAR2015.9745.

37. Шеуджен А.Х., Онищенко Л.М., Хурум Х.Д. Плодородие почвы и продуктивность люцерны при внесении микроудобрений. Плодородие. 2006. № 1. C. 18-19.

38. Arvind Kumar P.R., Channakeshava B.C., Siddaraju R. Effect Dates of Sowing and Cutting Intervals on Seed Yield and Quality of Alfalfa. Plant Archives. 2017. Vol. 17. No. 2. P. 1204-1208. ISSN 0972-5210.

39. Корягин Ю.В. Влияние биопрепаратов и микроэлементов на рост и развитие растений гороха Достижения науки и техники АПК. 2009. № 5. C. 26-28.

40. Корягин Ю.В. Влияние применения биопрепаратов и микроэлементов на посевные качества семян яровой пшеницы. Достижения науки и техники АПК. 2014. № 10. С. 29-30.

41. Siddiqui Z.A. PGPR: Biocontrol and Biofertilization. Netherlands, Springer. 2006. Ch. IV. P. 111-142. DOI: https://doi.org/10.1007/1-4020-4152-7.

42. Девликамов М.Р., Корягин Ю.В. Обработка яровой пшеницы селенизированными биопрепаратами и микроэлементами. Земледелие. 2007. № 3. С. 42-43.

43. Золоторева А.В., Дмитриева Ю.Н., Корягин Ю.В. Применение биопрепаратов при возделывании сои. XXI век: итоги прошлого и проблемы настоящего плюс. Серия: Экология. 2011. № 1(1). C. 134-137.

44. Цыганова Е.Н., Звягинцев Д.Г., Лысак Л.В., Степанов А.Л. Действие бактериально-гумусового препарата на биологическую активность почв. Почвоведение. 2013. Т. 46. № 7. С. 867-871.

45. Плескачев Ю.Н., Семина Н.И. Использование азотовита и фосфатовита при возделывании подсолнечника. Известия Нижневолжского агроуниверситетского комплекса. 2013. № 1. С. 53-56.
46. Елисеева Л.В., Каюкова О.В., Нестерова О.П. Влияние регуляторов роста на продуктивность сои в условиях Чувашской Республики. Вестник Марийского государственного университета. 2018. T. 4. № 3 (15). C. 22-27.

47. Елисеева Л.В., Каюкова О.В., Елисеев И.П. Влияние подкормок микробиологическими удобрениями на урожай и качество семян сои. Вестник Курской государственной сельскохозяйственной академии. 2019. № 2. C. 33-38.

48. Панкратова Е.М., Трефилова Л.В., Зяблых Р.Ю., Устюжанин И.А. Цианобактерия Nostoc paludosum Kutz как основа для создания агрономически полезных микробных ассоциаций на примере бактерий рода Rhizobium. Микробиология. 2008. Т. 77. № 2. C. 266-272.

49. Пацко О.В., Воробей Н.А., Коць С.Я., Паршикова Т.В. Дослідження есрективності агроконсорціумів азотфіксувальних мікроорганізмів. Физиол. биохим. культ. раст. 2010. Т. 42. № 2. С. 137-145.

50. Трефилова Л.В., Патрушева М.Н. Эффективность использования цианоризобиального консорциума при выращивании гороха посевного. Теоретическая и прикладная екологія. 2009. № 3. С. 67-75.

\section{References:}

1. Radović, J., Sokolović, D. \& Marković, J. (2009). Alfalfa-most important perennial forage legume in animal husbandry. Biotechnology in Animal Husbandry, 25 (5-6), 465-475. https://doi.org/10.2298/ BAH0906465R [in English].

2. Sokolović, D. et al. (2017). Genetic resources of perennial forage grasses in Serbia: Current State, Broadening and Evaluation. Selekcija i semenarstvo, 23 (1), 69-82. DOI: 10.5937/SelSem1701069S [in English].

3. Moga, I. \& Schitea, M. (2005). Tehnologii moderne de producere a seminţelor la plantele furajere. Ed. Ceres, Bucuresti, 288, 23-54 [in English].

4. Stanisavljević, R. (2012). Influence of plant density on yield components, yield and quality of seed and forage yields of alfalfa varieties. Romanian Agricultural Research, 29, 245-254 [in English].

5. Knezevic, J. (2014). Application of corn meal at ensiling of alfalfa cocksfoot and their mixture. Acta agriculturae Serbica, 19, 143-150. DOI: 10.5937/AASer1438143K [in English].

6. Iannucci, A., Di Fonzo, N. \& Martiniello, P. (2002). Alfalfa (Medicago sativa L.) seed yield and quality under different forage management systems and irrigation treatments in a Mediterranean environment. Field Crops Res, 78 (1), 65-74. https://doi.org/10.1016/ S0378-4290(02)00094-1 [in English].

7. Karamanos, A., Papastylianou, P., Stavrou, J. \& Avgoulas, C. (2009). Effects of Water Shortage and Air Temperature on Seed Yield and Seed Performance of Lucerne (Medicago sativa L.) in a Mediterranean Environment. J. Agron. \& Crop Sci, 195 (6), 408-419 [in English].

8. Putnam, D. \& Russelle, M. (2001). Alfalfa, wildlife and the environment. The importance and benefits of alfalfa in the 21st century. California: Alfalfa and Forage Association, 24 [in English].

9. Muthukumar Bagavathiannan, \& Rene C. Van Acker. (2009). The Biology and Ecology of Feral Alfalfa 
(Medicago sativa L.) and Its Implications for Novel Trait Confinement in North America. Critical Reviews in Plant Sciences, 28 (1-2), 69-87. DOI: $10.1080 / 07352680902753613$ [in English].

10. Hafarov, F.S. (2012). Sovershenstvovanie priemov vozdelyvanija ljucerny na semena v uslovijah Juzhnoj Lesostepi Respubliki Bashkortostan [Improvement of the methods of cultivation of alfalfa for seeds in the conditions of the Southern Forest-steppe of the Republic of Bashkortostan]. Extended abstract of candidate's thesis. Ufa [in Russian].

11. Denisov, E.A. (2010). Sovershenstvovanie tehnologicheskih priemov vozdelyvanie ljucerny na zelenuju massu i semena v Stepnoj zone Kuzneckoj kotloviny [Improvement of technological methods for the cultivation of alfalfa for green mass and seeds in the Steppe zone of the Kuznetsk depression]. Extended abstract of candidate's thesis. Barnaul [in Russian].

12. Orliuk, A.P. \& Honcharova, K.V. (2002). Adaptyvnyi $i$ produktyvnyi potentsial pshenytsi [Adaptive and productive potential of wheat]. Kherson [in Ukrainian].

13. Schitea, M. et al. (2007). New Romanian cultivars of alfalfa developed at NARDI Fundulea. Romanian Agric. Res., 24, 47-50 [in English].

14. Petolescu, C. et al. (2010). Intra-Population Genetic Diversity in Romanian Alfalfa Cultivars as Revealed by SSR Markers. Roman. Biotechnolog. Lett., 15, 107-112 [in English].

15. Tyshchenko, O.D. \& Tyshchenko, A.V. (2014). Naprjamy selekciji ljucerny dlja umov zroshennja [Directions of alfalfa selection for irrigation conditions]. Zroshuvane zemlerobstvo - Irrigated agriculture, 62, 93-95 [in Ukrainian].

16. Tyshchenko O.D. \& Tyshchenko A.V. (2014). Sorty selekciji Instytutu zroshuvanogho zemlerobstva [Varieties of selection of the Institute of Irrigated Agriculture]. Nasinnyctvo - Seed production, 3, 10-11 [in Ukrainian].

17. Bolanos-Aguilar, E.D. et al. (2000). Genetic control of alfalfa seed yield and its components. Plant Breed., 120, 67-72. https://doi.org/10.1046/ j.1439-0523.2001.00554.x [in English].

18. Kabir, et al. (2009). Effect of sowing time and cultivars on the growth and yield of chickpea under rainfed condition. Bangladesh J. Agric. Res., 34 (2), 335-342 [in English].

19. Tiwari, D. et al. (2016). Effect of Sowing Dates and Weed Management on Growth and Yield of Chickpea in Indo-Gangetic Plains. Proc. Natl. Acad. Sci., India, Sect. B Biol. Sci., 86, 33-38. https://doi.org/10.1007/ s40011-014-0396-6 [in English].

20. Gossen, B.D., Ukrainetz, H. \& Soroka, J.J. (2004). Effect of fertilizer on seed yield of alfalfa under irrigation in Saskatchewan. Can. J. Plant Sci., 84, 1105-1108. https://doi.org/10.4141/P03-136 [in English].

21. Terzić, D. (2011). The effect of cutting schedule, fertilization with micronutrients and plant growth regulation on yield and quality of alfalfa seed (Medicago sativa L.). Ph.D. Thesis. Belgrade [in English].

22. Kalinin, A.A., Kovina, A.L. \& Trefilova, L.V. (2017). Opyt primeneniya preparatov klubenkovykh bakteriy dlya povysheniya produktivnosti bobovykh kultur [Experience of using preparations of nodule bacteria to increase the productivity of legumes]. Ekologiya rodnogo kraya: problemy i puti ikh resheniya [Ecology of the native land: problems and solutions]. (pp. 293-298) [in Russian].

23. Ptashets, O.V. (2013). Sposoby regulirovaniya rostovykh protsessov lyutserny posevnoy [Methods for regulating the growth processes of sowing alfalfa]. Melioratsiya Land reclamation, 1 (69), 162-170 [in Russian].

24. Pankratova, E.M. et al. (2004). Konstruirovaniye mikrobnykh kultur na osnove sinezelenoy vodorosli Nostoc paludosum Kütz [Construction of microbial cultures based on the blue-green alga Nostoc paludosum Kütz]. Algologiya - Algology, 14 (4), 445-458 [in Russian].

25. Pankratova, Je.M. et al. (2004). Designing ofmicrobial binary cultures based on blue-green algae (Cyanobacteria) Nostoc paludosum Kütz. International Journal on Algae, 6 (3), 290-304 [in English].

26. Trefilova, L.V., Zyablykh, R.Yu., Kovina, A.L. \& Kalinin, A.A. (1998). Effektivnost tsianobakterialnykh konsortsiumov pri vygonke rassady kapusty $v$ zashchishchennom grunte. [Efficiency of cyanobacterial consortia in forcing cabbage seedlings in protected ground]. Vseross. nauchn.-prakt. konf. uchenykh $i$ spets. APK: "80 let s.kh. obrazovaniyu i nauki na Urale: Itogi i perspektivy" [All-Russian. scientific-practical. conf. scientists and specialists. Agro-industrial complex: "80 years of agriculture. Education and Science in the Urals: Results and Prospects"] (pp. 116-117). Perm [in Russian].

27. Naumkina, T.S. et al. (2012). Povysheniye effektivnosti biologicheskoy azotfiksatsii zernobobovykh kultur. [Increasing the efficiency of biological nitrogen fixation of leguminous crops.]. Zemledeliye - Agriculture, 5, 21-23 [in Russian].

28. Park, J. at all. (2010). Enhancing the solubility of insoluble phosphorus compounds by phosphate solubilizing bacteria. 19-th World Congress of Soil Science [in English].

29. Yasmin, H. \& Bano, A. (2011). Isolation and characterization of phosphate solubilizing bacteria from rhizosphere soil of weeds of khewra salt range and attock. Pakistan Journal of Botany, (3), 1663-1668 [in English].

30. Rodrıguez, H., Fraga, R., Gonzalez, T. \& Bashan, Y. (2006). Genetics of phosphate solubilization and its potential applications for improving plant growth promoting bacteria. Plant and Soil, 9, 15-21. DOI: 10.1007/s11104-006-9056-9 [in English].

31. Zhang, T. et al. (2009). Plant growth regulator effects on balancing vegetative and reproductive phases in alfalfa seed yield. Agron. J., 101, 1139-1145. DOI: https:// doi.org/10.2134/agronj2009.0017 [in English].

32. Jevtić, G., Radović, J. \& Lugić, Z. (2005). The effect of melliferous bee (Apis mellifera carnica Poll.) and mechanical means on seed yield, yield components and quality of alfalfa seed (Medicago sativa L.). Plant Breeding and Seed Produc., 11, 63-68 [in English].

33. Andjelković, B. et al. (2010). The influence of alfalfa flower coloration and the period of the day on the pollinator visits. Biotechnol. in Anim. Husban., 26, 173-180 [in English].

34. Zhang, T. et al. (2008). Effects of between-row and within-row spacing on alfalfa seed yields. Crop Sci., 48, 794-803. DOI: 10.2135/cropsci2007.06.0340 [in English]. 
35. Arvind Kumar, P.R., Channakeshava, B.C. \& Siddaraju, R. (2017). Effect dates of sowing and cutting time on seed yield and quality of alfalfa (Medicago sativa L.) CV. RL-88. Indian Journal of Agricultural Research, 51, 493-497. DOI: 10.18805/IJARe.A-4804 [in English].

36. Gawariya, S.C., Chopra, N.K., Chopra, N. \& Harika, A.S (2015). Effect of date of sowing and crop geometry on growth and yield parameters of forage mustard (Var. Chinese cabbage). African J. Agric. Res., 10 (33), 3292-3295. https://doi.org/10.5897/AJAR2015.9745 [in English].

37. Sheudzhen, A.Kh., Onishchenko, L.M. \& Khurum, Kh.D. (2006). Plodorodiye pochvy i produktivnost lyutserny pri vnesenii mikroudobreniy [Soil fertility and productivity of alfalfa with micronutrient fertilization]. Plodorodiye Fertility, 1, 18-19 [in Russian].

38. Arvind Kumar, P.R., Channakeshava, B.C. \& Siddaraju, R. (2017). Effect Dates of Sowing and Cutting Intervals on Seed Yield and Quality of Alfalfa. Plant Archives, 17 (2), 1204-1208 [in English].

39. Koryagin, Yu.V. (2009). Vliyaniye biopreparatov i mikroelementov na rost i razvitiye rasteniy gorokha [The influence of biological products and microelements on the growth and development of pea plants]. Dostizheniya nauki i tekhniki APK - Achievements of science and technology of the agro-industrial complex, 5, 26-28 [in Russian].

40. Koryagin, Yu.V. (2014). Vliyaniye primeneniya biopreparatov i mikroelementov na posevnyye kachestva semyan yarovoy pshenitsy [Influence of the use of biological products and microelements on the sowing quality of spring wheat seeds]. Dostizheniya nauki i tekhniki APK - Achievements of science and technology of the agro-industrial complex, 10, 29-30 [in Russian].

41. Siddiqui, Z.A. (ed.) (2006). PGPR: Biocontrol and Biofertilization. Dordrecht, Netherlands, Springer, 111-142. DOI: https://doi.org/10.1007/1-4020-4152-7 [in English].

42. Devlikamov, M.R. \& Koryagin, Yu.V. (2007). Obrabotka yarovoy pshenitsy selenizirovannymi biopreparatami i mikroelementami. [Processing of spring wheat with selenized biological products and microelements]. Zemledeliye - Agriculture, 3, 42-43 [in Russian].

43. Zolotoreva, A.V., Dmitriyeva, Yu.N. \& Koryagin, Yu.V. (2011). Primeneniye biopreparatov pri vozdelyvanii soi [The use of biological products in the cultivation of soybeans]. XXI vek: itogi proshlogo i problemy nastoyashchego plyus. Seriya: Ekologiya - XXI century: results of the past and problems of the present plus. Series: Ecology, 1 (1), 134-137 [in Russian].

44. Tsyganova, E.N., Zvyagintsev, D.G., Lysak, L.V. \& Stepanov, A.L. (2013). Deystviye bakterialnogumusovogo preparata na biologicheskuyu aktivnost pochv [The effect of a bacterial-humus preparation on the biological activity of soils]. Pochvovedeniye - Soil science, 46 (7), 867-871 [in Russian].

45. Pleskachev, Yu.N., Semina, N.I. (2013). Ispolzovaniye azotovita i fosfatovita pri vozdelyvanii podsolnechnika. [The use of nitrogen and phosphates for sunflower cultivation]. Izvestiya Nizhnevolzhskogo agrouniversitetskogo kompleksa - Bulletin of the Nizhnevolzhsky agro-university complex, 1, 53-56 [in Russian].
46. Eliseyeva, L.V., Kayukova, O.V. \& Nesterova, O.P. (2018). Vliyaniye regulyatorov rosta na produktivnost soi v usloviyakh Chuvashskoy Respubliki [The influence of growth regulators on soybean productivity in the Chuvash Republic]. Vestnik Mariyskogo gosudarstvennogo universiteta - Bulletin of the Mari State University, 4 (3), 22-27 [in Russian].

47. Eliseyeva, L.V., Kayukova, O.V. \& Eliseyev, I.P. (2019). Vliyaniye podkormok mikrobiologicheskimi udobreniyami na urozhay i kachestvo semyan soi [Influence of fertilizing with microbiological fertilizers on the yield and quality of soybean seeds]. Vestnik Kurskoy gosudarstvennoy selskokhozyaystvennoy akademii - Bulletin of the Kursk State Agricultural Academy, 2, 33-38 [in Russian].

48. Pankratova, E.M., Trefilova, L.V., Zyablykh, R.Yu. \& Ustyuzhanin, I.A. (2008). Tsianobakteriya Nostoc paludosum Kutz kak osnova dlya sozdaniya agronomicheski poleznykh mikrobnykh assotsiatsiy na primere bakteriy roda Rhizobium [Cyanobacterium Nostoc paludosum Kutz as a basis for the creation of agronomically beneficial microbial associations by the example of bacteria of the genus Rhizobium]. Mikrobiologiya - Microbiology, 77 (2), 266-272 [in Russian].

49. Patsko, O.V., Vorobei, N.A., Kots, S.Ya. \& Parshykova, T.V. (2010). Doslidzhennia efektyvnosti ahrokonsortsiumiv azotfiksuvalnykh mikroorhanizmiv [Research of efficiency of agroconsortiums of nitrogenfixing microorganisms]. Fyzyol. byokhym. kult. rast Physiology, biochemistry of cultivated plants, 42 (2), 137-145 [in Ukrainian].

50. Trefilova, L.V. \& Patrusheva, M.N. (2009). Effektivnost ispolzovaniya tsianorizobialnogo konsortsiuma pri vyrashchivanii gorokha posevnogo [Efficiency of using a cyanorizobial consortium in growing peas]. Teoreticheskaya i prikladnaya ekologiya - Theoretical and applied ecology, 3, 67-75 [in Russian].

Тищенко А.В., Тищенко О.Д., Димов О.М., Пілярська О.О., Гальченко Н.М. Врожайність та посівні якості насіння сортів люцерни в умовах зрошення залежно від застосування бактеріальних препаратів

Мета. Метою статті $є$ визначення впливу бактеріальних препаратів на насіннєву продуктивність люцерни другого року життя, енергію проростання та лабораторну схожість насіння. Методи. Дослідження проводили у двофакторному польовому досліді. Фактор А - сорти люцерни: Унітро та Зоряна. Фактор В - бактеріальні препарати (обробка насіння): 1 - контроль (без обробки); 2 - Ризобофіт; 3 - Комплекс біопрепаратів (КБП); 4 - Ціанобактеріальний консорціум (ЦБК); 5 - Ціанобактеріальний препарат (ЦБП). Результати. Урожайність насіння під час моноінокуляції бульбочковими бактеріями (Ризобофіт) вища на 16,0-20,0\% порівняно 3 контролем і склала 271,8 кг/га у сорту Зоряна та 361,9 кг/га у сорту Унітро. Проте дія монокультури (Ризобофріт) щодо насіннєвої продуктивності була нижчою від трикомпонентних асоціацій з урожайністю насіння 303,6 кг/га (сорт Зоряна) та 398,8 кг/га (сорт Унітро). Високий ефект показав ціаноризобіальний консорціум (337,3; 424,6 кг/га), але максимальний результат за аналізованою ознакою отриманий у варіанті із 
застосуванням ЦБП, а саме 361,1 та 456,4 кг/га у сортів Зоряна і Унітро відповідно. В результаті досліджень установлено, що істотне підвищення показників посівних якостей насіння люцерни відзначено за інокуляції препаратами Ризобофіт, КБП, ЦПК, ЦПП. Інокуляція насіння сприяла збільшенню маси 1000 насінин порівняно з аналогічними показниками в контрольних варіантах: у сорту Унітро до 2,02-2,05 г, у сорту Зоряна до 2,03-2,06 г, або на 0,03-0,06 г. Установлено коефіцієнт детермінації між врожайністю насіння та масою 1000 насінин, що мав такий показник: $R^{2}=0,290$. Висновки. Дослідженнями встановлено, що застосування бактеріальних препаратів істотно збільшувало насіннєву продуктивність, масу 1000 насінин та покращувало посівні якості. Найбільший врожай насіння було отримано у сорту Унітро за оброблення насіння цианобактеріальним препаратом (456,4 кг/га). Найбільшу масу 1000 насінин отримали у сорту Зоряна за оброблення насіння ціанобактеріальним препаратом, що становила 2,06 г. Коефіцієнт детермінації між урожайністю насіння та масою 1000 насінин мав такий показник: $R^{2}=0,290$.

Ключові слова: продуктивність, зрошення, енергія проростання, лабораторна схожість, регресія, коефіцієнт детермінації.

Tishchenko O.D., Tishchenko A.V., Dymov O.M., Piliarska O.O., Galchenko N.M. Yield and crop quality seeds of breeds of alfalfa under irrigation depending on the application of bacterial preparations

Purpose. Determination of the effect of bacterial preparations on alfalfa seed productivity in the second year of life, germination energy and laboratory seed germination. Methods. The study was conducted in a two-factor field experiment. Factor A - alfalfa varieties: Unitro and Zoryana. Factor B - bacterial preparations (seed treatment): 1 - control (without treatment); 2 - Rhizobophyte; 3 - Complex of biological products (CBP); 4 - Cyanobacterial consortium (CBC); 5 - Cyanobacterial drug (CBD). Results. Seed yield during monoinoculation with nodule bacteria (Rhizobophyte) was higher by $16.0-20.0 \%$ compared to the control and amounted to $271.8 \mathrm{~kg} / \mathrm{ha}$ in the variety Zoryana and $361.9 \mathrm{~kg} / \mathrm{ha}$ - the variety Unitro. However, the effect of monoculture (Rhizobophyte) on seed productivity was lower than the three-component associations with seed yields of $303.6 \mathrm{~kg} / \mathrm{ha}$ (Zoryana variety) and $398.8 \mathrm{~kg} /$ ha (Unitro variety). The cyanorisobial consortium (337.3; $424.6 \mathrm{~kg} / \mathrm{ha}$ ) showed a high effect, but the maximum result on the analyzed basis was obtained in the variant with the use of CBD - 361.1 and $456.4 \mathrm{~kg} / \mathrm{ha}$ in the varieties Zoryana and Unitro, respectively. As a result of researches it is established that essential increase of indicators of sowing qualities of alfalfa seeds is noted at inoculation by drugs Rhizobofit, CBP, CBC, CBD. Seed inoculation contributed to an increase in the weight of 1000 seeds in comparison with similar indicators in the control variants: in the cultivar Unitro up to 2.02-2.05 $\mathrm{g}$ and in the cultivar Zoryana - up to $2.03-2.06 \mathrm{~g}$, or by $0.03-0.06 \mathrm{~g}$. The coefficient of determination between seed yield and weight of 1000 seeds was set, which was $R^{2}=0.290$. Conclusions. Studies have shown that the use of bacterial preparations significantly increased seed productivity, weight of 1000 seeds and improved sowing qualities. The highest seed yield was obtained in the Unitro variety for seed treatment with cyanobacterial preparation $(456.4 \mathrm{~kg} / \mathrm{ha})$. The highest weight of 1000 seeds was obtained in the variety Zoryana for seed treatment with cyanobacterial preparation, which was $2.06 \mathrm{~g}$. The coefficient of determination between seed yield and weight of 1000 seeds was $R^{2}=0.290$.

Key words: productivity, irrigation, germination energy, laboratory germination, regression, coefficient of determination. 